\title{
Strong Cation Exchange Chromatography in Analysis of Posttranslational Modifications: Innovations and Perspectives
}

\author{
Mariola J. Edelmann \\ Institute for Genomics, Biocomputing \& Biotechnology; Mississippi Agricultural and Forestry Experiment Station, \\ Mississippi State University, 650 Stone Boulevard, MS 39762, USA \\ Correspondence should be addressed to Mariola J. Edelmann, mje100@mafes.msstate.edu \\ Received 10 May 2011; Accepted 7 September 2011 \\ Academic Editor: George Makhatadze \\ Copyright ( $) 2011$ Mariola J. Edelmann. This is an open access article distributed under the Creative Commons Attribution \\ License, which permits unrestricted use, distribution, and reproduction in any medium, provided the original work is properly \\ cited. \\ Strong cation exchange (SCX) chromatography has been utilized as an excellent separation technique that can be combined with \\ reversed-phase (RP) chromatography, which is frequently used in peptide mass spectrometry. Although SCX is valuable as the \\ second component of such two-dimensional separation methods, its application goes far beyond efficient fractionation of complex \\ peptide mixtures. Here I describe how SCX facilitates mapping of the protein posttranslational modifications (PTMs), specifically \\ phosphorylation and N-terminal acetylation. The SCX chromatography has been mainly used for enrichment of these two PTMs, \\ but it might also be beneficial for high-throughput analysis of other modifications that alter the net charge of a peptide.
}

\section{Introduction}

Posttranslational modifications (PTMs) regulate protein function, subcellular localization, and degradation. Although detection of the modified residues is crucial for understanding of the physiological roles of proteins as well as their mechanisms and pathways, it still represents a challenge. It is especially true in case of global proteome studies, in which hundreds or thousands of modified sites are monitored at the same time, and such analyses are becoming now more required due to an increasing popularity of the systems biology approaches. There is therefore a great demand for further development of efficient tools that could be used to characterize the entire complement of modified proteins in cells. Mass-spectrometry-based proteomics offers highly sensitive tools for modification mapping (reviewed in $[1,2])$, where thousands of proteins can be concurrently analyzed to construct and validate comprehensive physiological models. Nevertheless, PTM analysis usually requires preceding enrichment methods due to the high complexity of the samples and the low abundance of modified peptides. In this paper I will discuss strong cation exchange (SCX) chromatography as an effective method for enrichment of PTMs, including phosphorylation and N-terminal acetylation (summarized in Table 1).

\section{Principles of SCX Separation for Proteomic Applications}

The SCX stationary phase usually contains aliphatic sulfonic acid groups that are negatively charged in aqueous solution, therefore tightly binding any strongly basic analytes. To recover the analyte, the resin is then washed with a solvent neutralizing this ionic interaction. Most tryptic peptides in acidic $\mathrm{pH}$ are characterized by a net charge of +2 and above, and they can be therefore separated by SCX from peptides possessing a net charge of +1 , such as trypsin-generated phosphopeptides, C-terminal peptides, or peptides with blocked N-termini (i.e., peptides with blocked $\mathrm{N}$-terminal free amine group, for instance, by $\mathrm{N}$-acetylation), as well as from peptides containing higher charges, including ones containing missed cleavages and therefore more arginine and lysine residues [3]. Trypsin is not the only enzyme used to generate peptides for proteomic analyses, and other 
TABLE 1: Overview of the SCX chromatography methods used for PTM analysis described in this paper.

\begin{tabular}{|c|c|c|c|c|c|c|c|}
\hline Sample type & $\begin{array}{c}\text { Protein } \\
\text { amount/cell } \\
\text { number }\end{array}$ & $\begin{array}{l}\text { A number of } \\
\text { fractions } \\
\text { collected }\end{array}$ & $\begin{array}{c}\text { Mass } \\
\text { spectrometer } \\
\text { used } \\
\end{array}$ & $\begin{array}{l}\text { Experimental } \\
\text { workflow }\end{array}$ & Other details & PTM analysis & References \\
\hline HeLa cells & $8 \mathrm{mg}$ protein & $\begin{array}{c}4 \text { early } \\
\text { fractions } \\
\text { from each gel } \\
\text { band }\end{array}$ & $\begin{array}{l}\text { LCQ DECA } \\
\text { XP ion trap }\end{array}$ & $\begin{array}{c}\text { SDS-PAGE } \\
(10 \text { gel bands }) \rightarrow \\
\text { SCX } \rightarrow \\
\text { LC-MS/MS }\end{array}$ & & $\begin{array}{l}2002 \text { phosphorylation } \\
\text { sites identified from } \\
967 \text { proteins }\end{array}$ & {$[6]$} \\
\hline HeLa cells & $\begin{array}{l}0.5 \mathrm{mg} \\
\text { protein }\end{array}$ & 10 fractions & $\begin{array}{c}\text { LTQ- } \\
\text { Orbitrap }\end{array}$ & $\begin{array}{c}\mathrm{SCX} \rightarrow \mathrm{TiO}_{2} \rightarrow \\
\mathrm{LC}-\mathrm{MS} / \mathrm{MS}\end{array}$ & & $\begin{array}{l}722 \text { nonredundant } \\
\text { phosphorylation sites }\end{array}$ & [7] \\
\hline $\begin{array}{l}\text { Human Chang } \\
\text { liver cells }\end{array}$ & $\begin{array}{l}1.5 \mathrm{mg} \\
\text { protein }\end{array}$ & 40 fractions & $\begin{array}{l}\text { Q-TOF and } \\
\text { LCQ }\end{array}$ & $\begin{array}{l}\mathrm{SCX} \rightarrow \mathrm{TiO}_{2} \rightarrow \\
\mathrm{LC}-\mathrm{MS} / \mathrm{MS}\end{array}$ & & $\begin{array}{l}1035 \text { phosphorylation } \\
\text { sites from } 607 \\
\text { phosphoproteins }\end{array}$ & {$[8]$} \\
\hline $\begin{array}{l}\text { Escherichia coli } \\
\text { cells }\end{array}$ & $20 \mathrm{mg}$ protein & 10 fractions & $\begin{array}{l}\text { LTQ- } \\
\text { Orbitrap }\end{array}$ & $\begin{array}{l}\mathrm{SCX} \rightarrow \mathrm{TiO}_{2} \rightarrow \\
\mathrm{LC}-\mathrm{MS} / \mathrm{MS}\end{array}$ & $\begin{array}{l}\text { Lys-C digestion } \\
\text { followed by } \\
\text { trypsin } \\
\text { digestion }\end{array}$ & $\begin{array}{l}81 \text { phosphorylation } \\
\text { sites from } 79 \text { proteins }\end{array}$ & {$[9]$} \\
\hline $\begin{array}{l}\text { Bacillus subtilis } \\
\text { cells }\end{array}$ & $10 \mathrm{mg}$ protein & 15 fractions & $\begin{array}{l}\text { LTQ- } \\
\text { Orbitrap or } \\
\text { LTQ-FT }\end{array}$ & $\begin{array}{l}\mathrm{SCX} \rightarrow \mathrm{TiO}_{2} \rightarrow \\
\mathrm{LC}-\mathrm{MS} / \mathrm{MS}\end{array}$ & $\begin{array}{l}\text { Lys-C digestion } \\
\text { followed by } \\
\text { trypsin } \\
\text { digestion }\end{array}$ & $\begin{array}{l}78 \text { phosphorylation } \\
\text { sites from } 78 \text { proteins }\end{array}$ & {$[10]$} \\
\hline HeLa cells & $40 \mathrm{mg}$ protein & 25 fractions & $\begin{array}{l}\text { QSTAR } \\
\text { ELITE }\end{array}$ & $\begin{array}{l}\text { IMAC } \rightarrow \text { SCX } \\
\rightarrow \text { LC-MS/MS }\end{array}$ & & $\begin{array}{l}\sim 4512 \text { phosphorylated } \\
\text { sites }\end{array}$ & {$[11]$} \\
\hline HEK293 cells & $1 \mathrm{mg}$ protein & 40 fractions & $\begin{array}{l}\text { LTQ- } \\
\text { Orbitrap }\end{array}$ & $\begin{array}{c}\mathrm{SCX} \rightarrow \\
\mathrm{LC}-\mathrm{MS} / \mathrm{MS}\end{array}$ & $\begin{array}{l}\text { Lys-N, Lys-C, } \\
\text { and trypsin } \\
\text { digestion }\end{array}$ & $\begin{array}{l}5036 \text { nonredundant } \\
\text { phosphorylation sites }\end{array}$ & {$[4]$} \\
\hline $\begin{array}{l}\text { Human } \\
\text { embryonic stem } \\
\text { cells }\end{array}$ & $10 \mathrm{mg}$ protein & 12 fractions & $\begin{array}{l}\text { LTQ- } \\
\text { Orbitrap }\end{array}$ & $\begin{array}{l}\mathrm{SCX} \rightarrow \mathrm{IMAC} \\
\rightarrow \mathrm{LC}-\mathrm{MS} / \mathrm{MS}\end{array}$ & $\begin{array}{l}\text { CID and ETD } \\
\text { fragmentation } \\
\text { methods used in } \\
\text { mass } \\
\text { spectrometry }\end{array}$ & $\begin{array}{l}10844 \text { nonredundant } \\
\text { phosphorylation sites }\end{array}$ & {$[12]$} \\
\hline $\begin{array}{l}\text { Membrane } \\
\text { fraction of } \\
\text { human } \\
\text { teratocarcinoma } \\
\mathrm{Nt} 2 / \mathrm{d} 1 \text { cells }\end{array}$ & $5 \times 10^{6}$ cells & $\sim 30$ fractions & $\begin{array}{l}\text { LTQ- } \\
\text { Orbitrap }\end{array}$ & $\begin{array}{c}\mathrm{SCX} \rightarrow \\
\mathrm{LC}-\mathrm{MS} / \mathrm{MS}\end{array}$ & $\begin{array}{l}\text { Lys-C digestion } \\
\text { followed by } \\
\text { trypsin } \\
\text { digestion }\end{array}$ & $116 \mathrm{~N}$-acetylated sites & {$[13]$} \\
\hline HEK293 cells & $\begin{array}{c}12.3 \mathrm{mg} \\
\text { protein } / 6 \times \\
10^{7} \text { cells }\end{array}$ & 49 fractions & $\begin{array}{l}\text { LTQ XL } \\
\text { Linear ion } \\
\quad \text { trap }\end{array}$ & $\begin{array}{c}\text { SCX } \rightarrow \\
\text { LC-MS/MS }\end{array}$ & $\begin{array}{l}\text { CID and ETD } \\
\text { fragmentation } \\
\text { methods used in } \\
\text { mass } \\
\text { spectrometry, } \\
\text { Lys-N digestion }\end{array}$ & $\mathrm{N}$-acetylated peptides & {$[14]$} \\
\hline $\begin{array}{l}\text { Cytoplasmic, } \\
\text { nuclear, and } \\
\text { membrane } \\
\text { fractions from } \\
\text { Kc } 167 \text { cells } \\
\text { (Drosophila } \\
\text { melanogaster) }\end{array}$ & $\mathrm{n} / \mathrm{a}$ & $\mathrm{n} / \mathrm{a}$ & $\begin{array}{l}\text { HCT ion } \\
\text { trap, LTQ } \\
\text { linear ion } \\
\text { trap, and } \\
\text { XCT-Ultra } \\
\text { ion trap }\end{array}$ & $\begin{array}{l}\text { SCX } \rightarrow \\
\text { COFRADIC } \rightarrow \\
\text { LC-MS/MS }\end{array}$ & & $861 \mathrm{~N}$-acetylated sites & {$[15]$} \\
\hline HEK293 cells & $1 \mathrm{mg}$ protein & $\sim 40$ fractions & $\begin{array}{l}\text { LTQ- } \\
\text { Orbitrap }\end{array}$ & $\begin{array}{l}\mathrm{SCX} \rightarrow \\
\mathrm{LC}-\mathrm{MS} / \mathrm{MS}\end{array}$ & $\begin{array}{l}\text { Lys-N, Lys-C, } \\
\text { and trypsin } \\
\text { digestion }\end{array}$ & $\begin{array}{l}1391 \mathrm{~N} \text {-acetylated } \\
\text { peptides }\end{array}$ & {$[16]$} \\
\hline
\end{tabular}

SCX: strong cation exchange; PTMs: post-translational modifications; IMAC: immobilized metal affinity chromatography; ETD: electron transfer dissociation; CID: collision-induced dissociation; COFRADIC: combined fractional diagonal chromatography; LC-MS/MS: liquid chromatography-tandem mass spectrometry; n/a: data not available. 
proteolytic enzymes are also utilized, for instance, Lys-N, Lys-C, Glu-C, or elastase. Some of these enzymes can be used to obtain peptides characterized by specific, distinguishable net charges, which provide additional advantages for SCX separation of differently modified peptides $[4,5]$.

\section{SCX in Phosphoproteome Studies}

The complex system of signal transduction enables effective and targeted cell responses to external or internal stimuli, and PTMs play here a major role. Phosphorylation is one of the best characterized among these PTMs. This modification has been shown to affect approximately $30 \%$ of all the human proteins [17], although recent studies suggest that this percentage is even higher [18]. Protein phosphorylation has been associated with a wide range of cellular processes, such as proliferation, migration, differentiation, cell cycle progression, and apoptosis $[19,20]$. The mass spectrometric analysis of phosphopeptides can be very challenging for several reasons. Firstly, these negatively charged peptides are not easily analyzed in a positive mode, and this method of ionization is typically used in the electrospray ionization- (ESI-) based peptide mass spectrometry. Secondly, the hydrophilic property of phosphopeptides lowers their binding to the C18-based trapping columns used for purification of the peptide sample prior to its separation by HPLC. Thirdly, due to the ion suppression, detection of phosphopeptides by a mass spectrometer is problematic, especially in the complex samples containing unmodified or other more easily detectable peptides. Some of the above problems are still questionable, as discussed in [21], but the sole complexity of the peptide samples usually calls for prior enrichment in order to specifically select for phosphopeptides/phosphoproteins. These techniques include purification by phosphospecific antibodies $[22,23]$ and use of immobilized metal affinity chromatography (IMAC), where negatively charged phosphopeptides bind to positively charged metal ions, such as $\mathrm{Fe}^{3+}, \mathrm{Ga}^{3+}$, or $\mathrm{Zr}^{4+}$ $[2,24-26]$, as well as separation by titanium dioxide $\left(\mathrm{TiO}_{2}\right)$ columns $[27,28]$. Second chromatography dimension is also frequently utilized, and this might include hydrophilic interaction chromatography (HILIC) [29-32], electrostatic repulsion hydrophilic interaction chromatography (ERLIC) [11], and here discussed SCX.

The SCX chromatography is the most widely used HPLC fractionation method, and it has also found applications in phosphoproteomics (Table 1). The peptides are eluted from an SCX column using a low-pH buffer, and in these conditions phosphopeptides have a net charge of 0 or +1 , as opposed to a majority of other tryptic peptides characterized by +2 or higher net charges. Therefore, most of the phosphopeptides elute in the first few SCX fractions, although this depends on the type of gradient used and on a number of fractions collected [3,33-35].

Because of these features, the SCX chromatography can be employed as a stand-alone method for phosphopeptide mapping, as demonstrated by Beausoleil et al. [6], who used it without additional IMAC or $\mathrm{TiO}_{2}$ phosphopeptide enrichment. In this experiment $8 \mathrm{mg}$ of the nuclear protein extract derived from HeLa cells was first separated by SDSPAGE, then ten gel bands were digested by trypsin and the peptides were resolved by SCX, where only the first four fractions were collected for subsequent LC-MS/MS analysis by LCQ DECA XP ion trap. This simple workflow allowed for identification of 2002 phosphorylation sites from 967 proteins. Adding another dimension to this separation, such as an off-gel fractionation, which is based on the isoelectric point of peptides/proteins, might result in even larger number of identified phosphopeptides without enrichment by IMAC, $\mathrm{TiO}_{2}$, or phosphospecific antibodies.

Due to the complexity of the protein samples, SCXbased phosphopeptide separation alone is often ineffective, and the secondary phosphopeptide enrichment is necessary for identification of a larger number of phosphorylated residues [33, 36, 37]. For instance, an automated SCX$\mathrm{TiO}_{2}$-RP-LC-MS/MS method was used to separate HeLa protein digest, where 722 nonredundant phosphorylation sites were identified, including several doubly and triply phosphorylated peptides [7]. Briefly, $500 \mu \mathrm{g}$ of HeLa protein extract was digested, and these peptide mixtures were separated either by SCX or strong anion exchange (SAX) columns. In case of SCX, each of ten SCX fractions was additionally subjected to the phosphopeptide enrichment by $\mathrm{TiO}_{2}$. The samples were analyzed by the LTQ-Orbitrap mass spectrometer combined with C18-based HPLC. This SCX method was complementary to the on-line SAX separation, which however did not use subsequent $\mathrm{TiO}_{2}$ enrichment. In comparison with SCX, the latter method was able to separate a higher number of multiply phosphorylated peptides [7], but this could be due to the $\mathrm{TiO}_{2}$ enrichment used after the SCX chromatography which is known to be less ideal for multiply phosphorylated peptide analysis. Furthermore, Sui et al. used similar SCX separation followed by $\mathrm{TiO}_{2}$ enrichment and LC-MS/MS analysis to map the phosphoproteome in human Chang liver cell line [8]. In this experiment, $1.5 \mathrm{mg}$ protein was digested with trypsin and subjected to separation by SCX chromatography into forty fractions, followed by enrichment by $\mathrm{TiO}_{2}$ and LC-MS/MS analysis by Q-TOF and LCQ mass spectrometers. This study identified 1035 phosphorylation sites on 607 phosphoproteins, including a large fraction of previously unknown phosphoproteins, and the functional analysis demonstrated that majority of these proteins were involved in liver metabolism. Finally, similar procedure has been used for the phosphoproteome analysis of a Gram-negative bacterium Escherichia coli, where 81 phosphorylation sites were identified on 79 proteins [9]. In this study, $20 \mathrm{mg}$ protein was digested with Lys-C followed by tryptic digestion. The resulted peptides were split into two technical replicates and separated on SCX column into ten fractions, followed by $\mathrm{TiO}_{2}$ phosphopeptide purification and analysis by HPLC coupled to LTQ-Orbitrap mass spectrometer. A comparison of this dataset to a phosphoproteomic study of bacterium Bacillus subtilis [10] indicated that both phosphoproteomes demonstrate high conservation levels, and the authors suggested that some phosphorylation sites are conserved from Archaea to humans [9]. The Bacillus subtilis study has been done using a very similar technique to the one described for E. coli [9], but $10 \mathrm{mg}$ protein was 
used for analysis and fifteen SCX fractions were collected, which were then subjected to the $\mathrm{TiO}_{2}$ chromatography and analysis by HPLC coupled to LTQ-Orbitrap or LTQ-FT mass spectrometry.

Although SCX is a relatively old separation method, it still performs quite well if compared with newer HPLC techniques. Chen et al. [11] evaluated four different chromatography methods in terms of their capabilities to separate phosphopeptides of HeLa cells, and these included SCX, HILIC, ERLIC chromatography with nonvolatile solvent system (ERLIC-nV), and ERLIC with volatile solvent system (ERLIC-V). Each chromatography method was performed on peptides obtained from $40 \mathrm{mg}$ protein. Phosphopeptides were first enriched on IMAC, followed by SCX, HILIC, ERLIC-nV, or ERLIC-V-based separation into multiple fractions ( 25 fractions in case of SCX) and finally analyzed by LCMS/MS using QSTAR ELITE mass spectrometer. As a result, each technique yielded between 4000 and 5000 phosphopeptides, including a large number of nonoverlapping phosphopeptides for each HPLC method. Together, the data from all four chromatography analyses generated 9069 unique phosphopeptides, demonstrating a complementary nature of these different chromatography methods. Interestingly, the phosphopeptide resolving power was the greatest for the SCX method (60.52\% nonrepetitive phosphopeptides), followed by ERLIC-nV (50.79\% nonrepetitive phosphopeptides), while the lowest performance was assigned to HILIC (50.83\% nonrepetitive phosphopeptides), which also had the worst orthogonality relative to reversed-phase chromatography.

Apart from combining SCX separation with additional phosphopeptide enrichment methods, another innovation is to utilize other proteolytic enzymes for peptide generation in order to complement the data obtained from trypsin-digested samples. An example is Lys-N $[4,5]$ that generates phosphopeptides characterized by distinct net charges, which can be thus efficiently separated by SCX and distinguished from the $\mathrm{N}$-acetylated peptide populations [4]. This feature of Lys-N has been taken advantage of in a study where a parallel use of Lys- $\mathrm{N}$, trypsin, and Lys-C digestion followed by SCX and LC-MS/MS analysis provided a total of 5036 nonredundant phosphopeptides [4]. In this study only $1 \mathrm{mg}$ protein was subjected to digestion with one of these proteolytic enzymes. The peptides were then desalted on C18 columns and subjected to the SCX-based fractionation. Forty thus obtained SCX fractions were analyzed by HPLC combined with LTQ-Orbitrap mass spectrometry. Lys-N increased the phosphopeptide coverage by $72 \%$ if compared with the trypsin-digested sample, whereas trypsin accounted for only $25 \%$ of the increase. Clearly, future exploration of other proteolytic enzymes can additionally benefit the global phosphoproteome studies.

In addition, the mass spectrometry methods can also be modified to fully exploit the phosphopeptide separation capabilities provided by SCX. As an example, electron transfer dissociation (ETD) has emerged as an alternative to collision-induced dissociation (CID) fragmentation method used in mass spectrometry. ETD is especially suitable for analysis of highly charged peptides and for PTMs that are labile upon CID fragmentation methods [38]. As an example, this approach has been used to characterize phosphoproteome of human embryonic stem cells [12]. In this study, peptides obtained from $10 \mathrm{mg}$ protein lysate were subjected to the SCX separation into twelve fractions, followed by IMAC phosphopeptide purification and LC-MS/MS analysis by the LTQ-Orbitrap mass spectrometer. The peptides were analyzed using ETD and CID fragmentation methods, which resulted in the identification of 10,844 nonredundant phosphorylation sites. Importantly, the ETD method yielded a much larger number of unique phosphopeptides than CID $(8,087$ in comparison with 3,868$)$. In this study, ETD fragmentation analysis has been also shown to more frequently localize the phosphorylation site to a specific residue, which is often problematic when using CID fragmentation [12].

Finally, my preliminary data suggests that SCX chromatography resins can be further optimized in terms of their phosphopeptide enrichment properties. I used $\mathrm{TiO}_{2}$ resin as well as cartridges containing three different SCX resins to separate phosphorylated peptides of several forms of casein, followed by LS-MS/MS analysis (please, refer to the Supplementary methods in Appendix). The SCX resins included sulfonic acid (SCX-1), propyl sulfonic acid (SCX-2), and ethylbenzene sulfonic acid (SCX-3), and their performance varied in terms of their phosphopeptide enrichment potential. In this experiment, SCX-3 has been shown to be the most efficient column among the tested resins (Figure 1). Due to the presence of an aromatic ring, SCX-1 and SCX-3 resins have nonpolar character, therefore enhancing nonpolar secondary interactions with the analyte and increasing its binding to the column. However, SCX-3 might have also other characteristics that enable for a slightly better separation of phosphopeptides. This preliminary study should be repeated using a more complex sample, but it demonstrates that there might be a bigger potential for the SCX-based separation methods if these resins are further optimized specifically for phosphorylation analysis.

\section{Utilizing SCX Chromatography in Analysis of N-Terminal Acetylation}

The N-terminal acetylation is a common protein modification with a relatively unclear physiological role. It affects a variety of protein functions, such as enzymatic activity, DNA-binding, and protein-protein interactions [39]. It might also represent a specific degron site, thus targeting proteins for ubiquitination and subsequent degradation [40]. The SCX-based separation of N-terminal acetylated peptides is based on the fact that these peptides lack the N-terminal free amine, which contributes to their earlier elution in the SCX chromatography [13] and enables their separation from slightly later migrating phosphopeptides (Table $1 ;[4,14]$ ).

One of the first attempts to use SCX for analysis of the $\mathrm{N}$-acetylated and $\mathrm{C}$-terminal peptides showed that this approach, if adequately optimized, can provide 95\% specificity for this peptide class [13]. The membraneenriched fraction from $5 \times 10^{6}$ human teratocarcinoma $\mathrm{Nt}$ /d1 cells was digested with Lys-C, followed by tryptic digestion. The peptides were desalted with a C18 column 


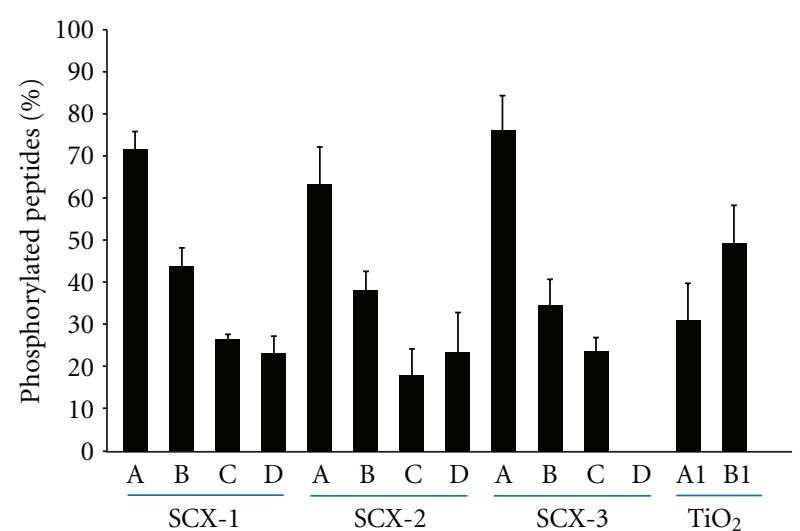

FIgUre 1: Phosphopeptide enrichment capabilities for various SCX resins. $50 \mu \mathrm{g}$ casein was digested with trypsin and loaded in triplicates onto SCX-1, SCX-2, SCX-3 cartridges, and $\mathrm{TiO}_{2}$-packed tips, followed by peptide elution. In case of the SCX cartridges, the sequential peptide elution was done using four buffers (A-D) characterized by increasing molarity of ammonium acetate $(50,100$, 200 , or $500 \mathrm{nM}$ ammonium acetate). The $\mathrm{TiO}_{2}$ tips were preconditioned with $100 \%$ acetonitrile, conditioned with $0.2 \mathrm{M}$ phosphate buffer $\mathrm{pH} 7$, and equilibrated with solvent containing 50\% acetonitrile and $0.1 \%$ formic acid. The peptide sample was then loaded onto $\mathrm{TiO}_{2}$ resin, washed six times with buffer containing $50 \%$ acetonitrile, $0.1 \%$ formic acid, and $0.1 \mathrm{M} \mathrm{KCl}$, and eluted with $0.2 \mathrm{M}$ phosphate buffer $\mathrm{pH} 7$ and $0.5 \%$ aqueous ammonia; both $\mathrm{TiO}_{2}$ eluates were combined. The volume of each eluate was concentrated, and triplicate samples were analyzed by LC-MS/MS (Esquire HCTplus mass spectrometer, Bruker Daltonics). The displayed percentage of phosphorylated peptides was calculated for three forms of casein (UniProt accession numbers P02663, P02662, and P02663). Standard deviation was calculated using experimental triplicates.

and separated by SCX into approximately thirty fractions, which were then analyzed by the LC-LTQ-Orbitrap mass spectrometry. This workflow proved to be successful, and it allowed for identification of $116 \mathrm{~N}$-terminal acetylated residues, although a relatively small amount of protein material was used.

Moreover, similarly as in case of phosphoproteome analysis, the SCX-based separation of N-terminal acetylated peptides has been combined with the ETD fragmentation method [14], yielding results complementary to the ones obtained by the CID fragmentation. Digestion with proteolytic enzymes such as Lys-N and Lys-C has also been shown to be advantageous, for instance, due to already mentioned separation of the $\mathrm{N}$-terminally acetylated peptides from phosphopeptides $[4,14,16]$.

Furthermore, there are additional methods suitable for enrichment of the $\mathrm{N}$-terminal acetylated peptides that can be used in conjunction with SCX, and these include combined fractional diagonal chromatography (COFRADIC; summarized in [41]). For instance, SCX combined with COFRADIC and LC-MS/MS analysis by an ion trap mass spectrometer has been used to identify over 1,200 mature protein $\mathrm{N}$ termini, including $861 \mathrm{~N}$-terminal acetylation sites in cytoplasmic, nuclear, and membrane fractions obtained from Drosophila melanogaster cells [15].
In summary, the SCX methods used for mapping of the $\mathrm{N}$-terminal acetylation sites are expected to shed more light on the abundance and function of this prevalent but not wellunderstood modification.

\section{Conclusions}

Although current efforts are focused on optimizing the SCX chromatography for analysis of phosphorylation as a key signaling modification, this HPLC method has a potential to be used in analysis of other PTMs that alter a net charge of the peptides. For example, SCX could be possibly used in glycomics, based on the assumption that many extracellular $\mathrm{N}$-glycans contain sialic acid residues, thereby reducing the net charge of glycopeptides in comparison with the unmodified peptides [42]. Moreover, modifications of lysine and arginine residues, such as methylation or acetylation, also account for a shift in SCX elution time in comparison with their unmodified counterparts [43]. When compared to the whole complement of peptides, these modifications might not cause a sufficient change in elution properties in order to monitor these modifications on a global scale, but they can still be optimized to study modifications of specific proteins, such as histones that are characterized by multiple lysine and arginine PTMs. Moreover, differential elution of peptides containing modified arginine or lysine residues in comparison with peptides containing these amino acids in an unmodified form can be used as an additional validation of the proteomic results. All this further underlines the importance of the SCX chromatography in proteomic applications focused on investigation of protein modifications.

\section{Appendix}

\section{Supplementary Methods: Phosphopeptide Enrichment and Mass Spectrometry Analysis}

$50 \mu \mathrm{g}$ of casein (Sigma-Aldrich, UK) was digested with trypsin, as we previously described [44-46]. SCX (here referred to as SCX-1), SCX-2, and SCX-3 cartridges (ISOLUTE SCX $200 \mathrm{mg} / 3 \mathrm{~mL}$; Kinesis, UK) were washed with $5 \mathrm{~mL}$ wash solvent containing $0.1 \%$ formic acid and $5 \%$ acetonitrile. The digested protein samples were loaded onto SCX-1, SCX-2, or SCX-3 columns and washed twice with $5 \mathrm{~mL}$ wash solvent. The peptides were eluted sequentially with buffers $\mathrm{A}, \mathrm{B}, \mathrm{C}$, and $\mathrm{D}$, containing $5 \%$ acetonitrile as well as 50 , 100,200 , or $500 \mathrm{nM}$ ammonium acetate $\mathrm{pH} 3$, respectively. All the elution procedures were performed on a vacuum manifold (Kinesis, UK) connected to a vacuum pump.

For the phosphopeptide enrichment with $\mathrm{TiO}_{2}$ pipette tip (Gl Sciences, Japan), $\mathrm{TiO}_{2}$ tips were preconditioned with $100 \%$ acetonitrile, conditioned with $0.2 \mathrm{M}$ phosphate buffer pH7, and equilibrated with solvent containing 50\% acetonitrile and $0.1 \%$ formic acid. The peptide sample was then loaded onto the $\mathrm{TiO}_{2}$ tips, washed six times with buffer containing $50 \%$ acetonitrile, $0.1 \%$ formic acid, and $0.1 \mathrm{M}$ $\mathrm{KCl}$, and eluted with $0.2 \mathrm{M}$ phosphate buffer $\mathrm{pH} 7$ and $0.5 \%$ aqueous ammonia. 
The volume of all eluates was reduced in a vacuum centrifuge (Thermo, UK) and adjusted to appropriate volume with solvent containing $2 \%$ acetonitrile and $0.1 \%$ formic acid. The triplicates of samples $(\sim 1 \mu$ g protein $)$ were analyzed on HPLC (Ultimate 3000, Dionex, UK) attached to a $3 \mathrm{D}$ high-capacity ion trap mass spectrometer (Esquire HCTplus, Bruker Daltonics, UK), exactly as we previously described [44-46]. The obtained peak lists were submitted to the Mascot search engine, where phosphorylation on serine, threonine, and tyrosine was added as a variable modification in the search parameters. The peptide and fragment mass tolerances were 2.5 and 0.8 , respectively. Individual MS/MS spectra for peptides with a Mascot Mowse score lower than 40 were inspected manually and only included in the statistics if a series of at least four continuous $y$ or $b$ ions were observed. Standard variations for triplicate samples were calculated using Excel (Microsoft).

\section{Abbreviations}

$\begin{array}{ll}\text { SCX: } & \text { Strong cation exchange } \\ \text { RP: } & \text { Reversed phase } \\ \text { PTM: } & \text { Postranslational modification } \\ \text { ESI: } & \text { Electrospray ionization } \\ \text { IMAC: } & \text { Immobilized metal affinity chromatography } \\ \text { ETD: } & \text { Electron transfer dissociation } \\ \text { CID: } & \text { Collision-induced dissociation } \\ \text { HPLC: } & \text { High-performance liquid chromatography } \\ \text { COFRADIC: } & \text { Combined fractional diagonal } \\ & \text { chromatography } \\ \text { HILIC: } & \text { Hydrophilic interaction chromatography } \\ \text { ERLIC: } & \text { Electrostatic repulsion hydrophilic } \\ & \text { interaction chromatography } \\ \text { LC-MS/MS: } & \text { Liquid chromatography-tandem mass } \\ & \text { spectrometry. }\end{array}$

\section{Acknowledgments}

M. J. Edelmann is supported by EPS-0903787. She would like to thank Dr. Benedikt Kessler (Oxford University, UK) and Alison Cleeve (Kinesis Ltd., UK) for technical assistance with the SCX cartridges. The paper was approved for publication as a Journal Article no. J-12062 of the Mississippi Agricultural and Forestry Experiment Station, Mississippi State University.

\section{References}

[1] M. Mann, S. E. Ong, M. Grønborg, H. Steen, O. N. Jensen, and A. Pandey, "Analysis of protein phosphorylation using mass spectrometry: deciphering the phosphoproteome," Trends in Biotechnology, vol. 20, no. 6, pp. 261-268, 2002.

[2] H. Y. Wu and P. C. Liao, "Analysis of protein phosphorylation using mass spectrometry," Chang Gung Medical Journal, vol. 31, no. 3, pp. 217-227, 2008.

[3] S. Mohammed and A. J. Heck, "Strong cation exchange (SCX) based analytical methods for the targeted analysis of protein post-translational modifications," Current Opinion in Biotechnology, 2010.
[4] S. Gauci, A. O. Helbig, M. Slijper, J. Krijgsveld, A. J. R. Heck, and S. Mohammed, "Lys-N and trypsin cover complementary parts of the phosphoproteome in a refined SCX-based approach," Analytical Chemistry, vol. 81, no. 11, pp. 4493-4501, 2009.

[5] N. Taouatas, M. M. Drugan, A. J. R. Heck, and S. Mohammed, "Straightforward ladder sequencing of peptides using a Lys-N metalloendopeptidase," Nature Methods, vol. 5, no. 5, pp. 405-407, 2008.

[6] S. A. Beausoleil, M. Jedrychowski, D. Schwartz et al., "Largescale characterization of HeLa cell nuclear phosphoproteins," Proceedings of the National Academy of Sciences of the United States of America, vol. 101, no. 33, pp. 12130-12135, 2004.

[7] J. Dai, L. S. Wang, Y. B. Wu et al., "Fully automatic separation and identification of phosphopeptides by continuous $\mathrm{pH}$ gradient anion exchange online coupled with reversed-phase liquid chromatography mass spectrometry," Journal of Proteome Research, vol. 8, no. 1, pp. 133-141, 2009.

[8] S. Sui, J. Wang, B. Yang et al., "Phosphoproteome analysis of the human Chang liver cells using SCX and a complementary mass spectrometric strategy," Proteomics, vol. 8, no. 10, pp. 2024-2034, 2008.

[9] B. Macek, F. Gnad, B. Soufi et al., "Phosphoproteome analysis of E. coli reveals evolutionary conservation of bacterial Ser/ Thr/Tyr phosphorylation," Molecular and Cellular Proteomics, vol. 7, no. 2, pp. 299-307, 2008.

[10] B. Macek, I. Mijakovic, J. V. Olsen et al., "The serine/threonine/tyrosine phosphoproteome of the model bacterium Bacillus subtilis," Molecular and Cellular Proteomics, vol. 6, no. 4, pp. 697-707, 2007.

[11] X. Chen, D. Wu, Y. Zhao, B. H. Wong, and L. Guo, "In-creasing phosphoproteome coverage and identification of phosphorylation motifs through combination of different HPLC fractionation methods," Journal of Chromatography B, vol. 879, no. 1, pp. 25-34, 2011.

[12] D. L. Swaney, C. D. Wenger, J. A. Thomson, and J. J. Coon, "Human embryonic stem cell phosphoproteome revealed by electron transfer dissociation tandem mass spectrometry," Proceedings of the National Academy of Sciences of the United States of America, vol. 106, no. 4, pp. 995-1000, 2009.

[13] W. Dormeyer, S. Mohammed, B. Van Breukelen, J. Krijgsveld, and A. J. R. Heck, "Targeted analysis of protein termini," Journal of Proteome Research, vol. 6, no. 12, pp. 4634-4645, 2007.

[14] N. Taouatas, A. F. M. Altelaar, M. M. Drugan, A. O. Helbig, S. Mohammed, and A. J. R. Heck, "Strong cation exchangebased fractionation of Lys-N-generated peptides facilitates the targeted analysis of post-translational modifications," Molecular and Cellular Proteomics, vol. 8, no. 1, pp. 190-200, 2009.

[15] S. Goetze, E. Qeli, C. Mosimann et al., "Identification and functional characterization of N-terminally acetylated proteins in Drosophila melanogaster," PLoS Biology, vol. 7, no. 11, Article ID e1000236, 2009.

[16] A. O. Helbig, S. Gauci, R. Raijmakers et al., "Profiling of Nacetylated protein termini provides in-depth insights into the N-terminal nature of the proteome," Molecular and Cellular Proteomics, vol. 9, no. 5, pp. 928-939, 2010.

[17] P. Cohen, "The role of protein phosphorylation in human health and disease. The Sir Hans Krebs Medal Lecture," European Journal of Biochemistry, vol. 268, pp. 5001-5010, 2001.

[18] J. V. Olsen, B. Blagoev, F. Gnad et al., "Global, in vivo, and sitespecific phosphorylation dynamics in signaling networks," Cell, vol. 127, no. 3, pp. 635-648, 2006. 
[19] G. Manning, D. B. Whyte, R. Martinez, T. Hunter, and S. Sudarsanam, "The protein kinase complement of the human genome," Science, vol. 298, no. 5600, pp. 1912-1934, 2002.

[20] S. M. Thomas and J. S. Brugge, "Cellular functions regulated by SRC family kinases," Annual Review of Cell and Developmental Biology, vol. 13, pp. 513-609, 1997.

[21] H. Steen, J. A. Jebanathirajah, J. Rush, N. Morrice, and M. W. Kirschner, "Phosphorylation analysis by mass spectrometry: myths, facts, and the consequences for qualitative and quantitative measurements," Molecular and Cellular Proteomics, vol. 5, no. 1, pp. 172-181, 2006.

[22] A. Pandey, A. V. Podtelejnikov, B. Blagoev, X. R. Bustelo, M. Mann, and H. F. Lodish, "Analysis of receptor signaling pathways by mass spectrometry: identification of Vav-2 as a substrate of the epidermal and platelet-derived growth factor receptors," Proceedings of the National Academy of Sciences of the United States of America, vol. 97, no. 1, pp. 179-184, 2000.

[23] M. Grønborg, T. Z. Kristiansen, A. Stensballe et al., "A mass spectrometry-based proteomic approach for identification of serine/threonine-phosphorylated proteins by enrichment with phospho-specific antibodies: identification of a novel protein, Frigg, as a protein kinase A substrate," Molecular and Cellular Proteomics, vol. 1, no. 7, pp. 517-527, 2002.

[24] P. Cao and J. T. Stults, "Mapping the phosphorylation sites of proteins using on-line immobilized metal affinity chromatography/capillary electrophoresis/electrospray ionization multiple stage tandem mass spectrometry," Rapid Communications in Mass Spectrometry, vol. 14, no. 17, pp. 1600-1606, 2000.

[25] S. B. Ficarro, M. L. McCleland, P. T. Stukenberg et al., "Phosphoproteome analysis by mass spectrometry and its application to Saccharomyces cerevisiae," Nature Biotechno$\log y$, vol. 20, no. 3, pp. 301-305, 2002.

[26] T. S. Nühse, A. Stensballe, O. N. Jensen, and S. C. Peck, "Large-scale analysis of in vivo phosphorylated membrane proteins by immobilized metal ion affinity chromatography and mass spectrometry," Molecular and Cellular Proteomics, vol. 2, no. 11, pp. 1234-1243, 2003.

[27] M. W. H. Pinkse, P. M. Uitto, M. J. Hilhorst, B. Ooms, and A. J. R. Heck, "Selective isolation at the femtomole level of phosphopeptides from proteolytic digests using 2D-NanoLCESI-MS/MS and titanium oxide precolumns," Analytical Chemistry, vol. 76, no. 14, pp. 3935-3943, 2004.

[28] M. R. Larsen, T. E. Thingholm, O. N. Jensen, P. Roepstorff, and T. J. D. Jørgensen, "Highly selective enrichment of phosphorylated peptides from peptide mixtures using titanium dioxide microcolumns," Molecular and Cellular Proteomics, vol. 4, no. 7, pp. 873-886, 2005.

[29] H. Lindner, B. Sarg, and W. Helliger, "Application of hydrophilic-interaction liquid chromatography to the separation of phosphorylated H1 histones," Journal of Chromatography A, vol. 782, no. 1, pp. 55-62, 1997.

[30] D. E. McNulty and R. S. Annan, "Hydrophilic interaction chromatography reduces the complexity of the phosphoproteome and improves global phosphopeptide isolation and detection," Molecular and Cellular Proteomics, vol. 7, no. 5, pp. 971-980, 2008.

[31] D. E. McNulty and R. S. Annan, "Hydrophilic interaction chromatography for fractionation and enrichment of the phosphoproteome," Methods in Molecular Biology, vol. 527, pp. 93-105, 2009.

[32] R. A. Saleem and J. D. Aitchison, "Quantitative phosphoproteomics in fatty acid stimulated Saccharomyces cerevisiae," Journal of Visualized Experiments, vol. 32, 2009.
[33] J. Villén and S. P. Gygi, "The SCX/IMAC enrichment approach for global phosphorylation analysis by mass spectrometry," Nature Protocols, vol. 3, no. 10, pp. 1630-1638, 2008.

[34] M. J. Tanasijevic, M. G. Myers, R. S. Thoma, D. L. Crimmins, M. F. White, and D. B. Sacks, "Phosphorylation of the insulin receptor substrate IRS-1 by casein kinase II," Journal of Biological Chemistry, vol. 268, no. 24, pp. 18157-18166, 1993.

[35] J. C. Trinidad, C. G. Specht, A. Thalhammer, R. Schoepfer, and A. L. Burlingame, "Comprehensive identification of phosphorylation sites in postsynaptic density preparations," Molecular and Cellular Proteomics, vol. 5, no. 5, pp. 914-922, 2006.

[36] K. Højlund, B. P. Bowen, H. Hwang et al., "In vivo phosphoproteome of human skeletal muscle revealed by phosphopeptide enrichment and HPLC-ESI-MS/MS," Journal of Proteome Research, vol. 8, no. 11, pp. 4954-4965, 2009.

[37] G. Y. Soung, J. L. Miller, H. Koc, and E. C. Koc, "Comprehensive analysis of phosphorylated proteins of Escherichia coli ribosomes," Journal of Proteome Research, vol. 8, no. 7, pp. 3390-3402, 2009.

[38] N. L. Kelleher, R. A. Zubarev, K. Bush et al., "Localization of labile posttranslational modifications by electron capture dissociation: the case of $\gamma$-carboxyglutamic acid," Analytical Chemistry, vol. 71, no. 19, pp. 4250-4253, 1999.

[39] B. Polevoda and F. Sherman, "The diversity of acetylated proteins," Genome Biology, vol. 3, no. 5, article no. 0006, pp. 6.1-6.6, 2002.

[40] C. S. Hwang, A. Shemorry, and A. Varshavsky, "N-terminal acetylation of cellular proteins creates specific degradation signals," Science, vol. 327, no. 5968, pp. 973-977, 2010.

[41] N. Mischerikow and A. J. Heck, "Targeted large-scale analysis of protein acetylation,” Proteomics, vol. 11, no. 4, pp. 571-589, 2011.

[42] U. Lewandrowski, R. P. Zahedi, J. Moebius, U. Walter, and A. Sickmann, "Enhanced N-glycosylation site analysis of sialoglycopeptides by strong cation exchange prefractionation applied to platelet plasma membranes," Molecular and Cellular Proteomics, vol. 6, no. 11, pp. 1933-1941, 2007.

[43] P. A. Wilmarth, S. Tanner, S. Dasari et al., "Age-related changes in human crystalline determined from comparative analysis of post-translational modifications in young and aged lens: does deamidation contribute to crystallin insolubility?" Journal of Proteome Research, vol. 5, no. 10, pp. 2554-2566, 2006.

[44] M. Batycka, N. F. Inglis, K. Cook et al., "Ultra-fast tandem mass spectrometry scanning combined with monolithic column liquid chromatography increases throughput in proteomic analysis," Rapid Communications in Mass Spectrometry, vol. 20, no. 14, pp. 2074-2080, 2006.

[45] M. J. Edelmann, H. B. Kramer, M. Altun, and B. M. Kessler, "Post-translational modification of the deubiquitinating enzyme otubain 1 modulates active RhoA levels and susceptibility to Yersinia invasion," FEBS Journal, vol. 277, no. 11, pp. 2515-2530, 2010.

[46] M. J. Edelmann, A. Iphöfer, M. Akutsu et al., "Structural basis and specificity of human otubain 1-mediated deubiquitination," Biochemical Journal, vol. 418, no. 2, pp. 379-390, 2009. 

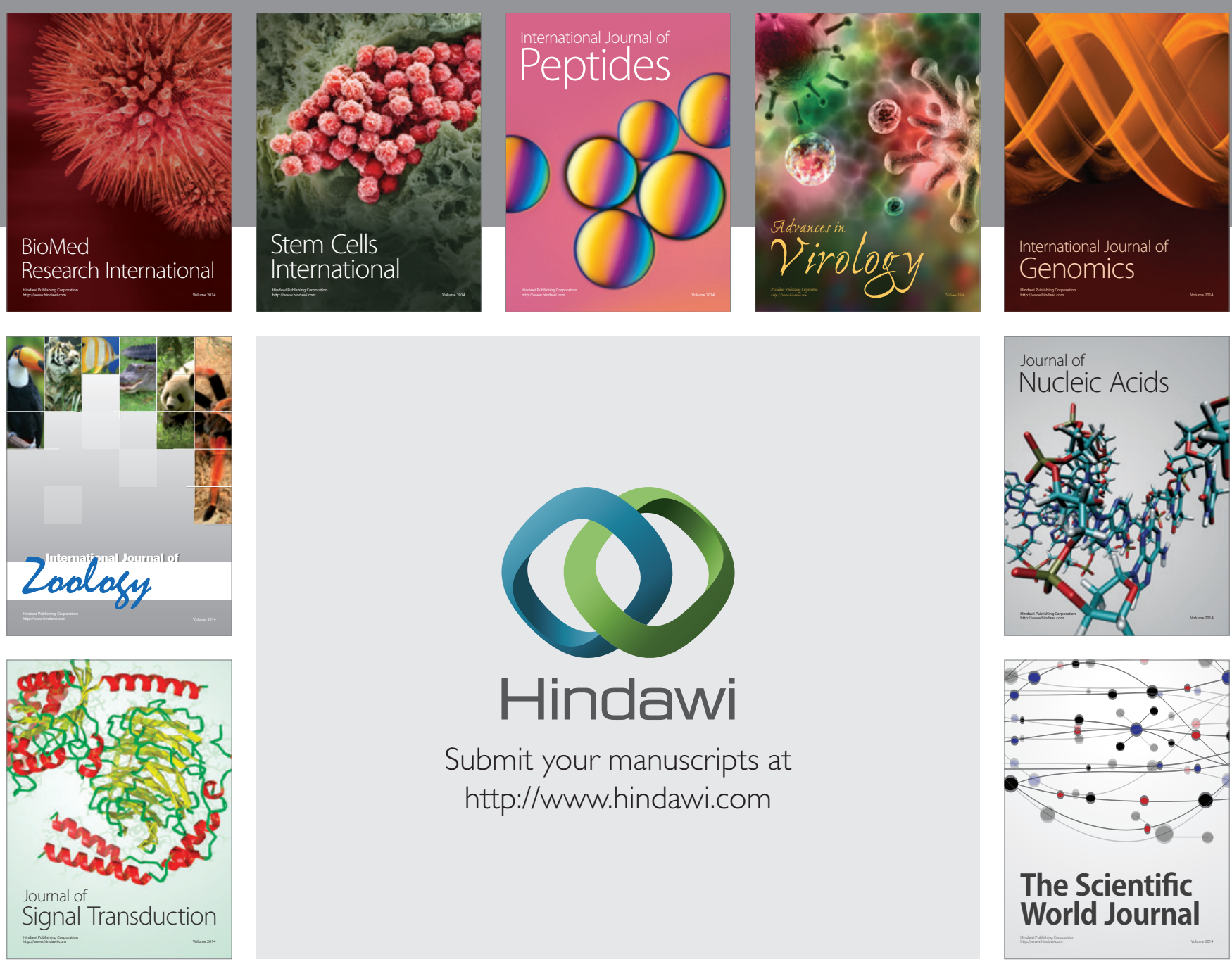

Submit your manuscripts at

http://www.hindawi.com
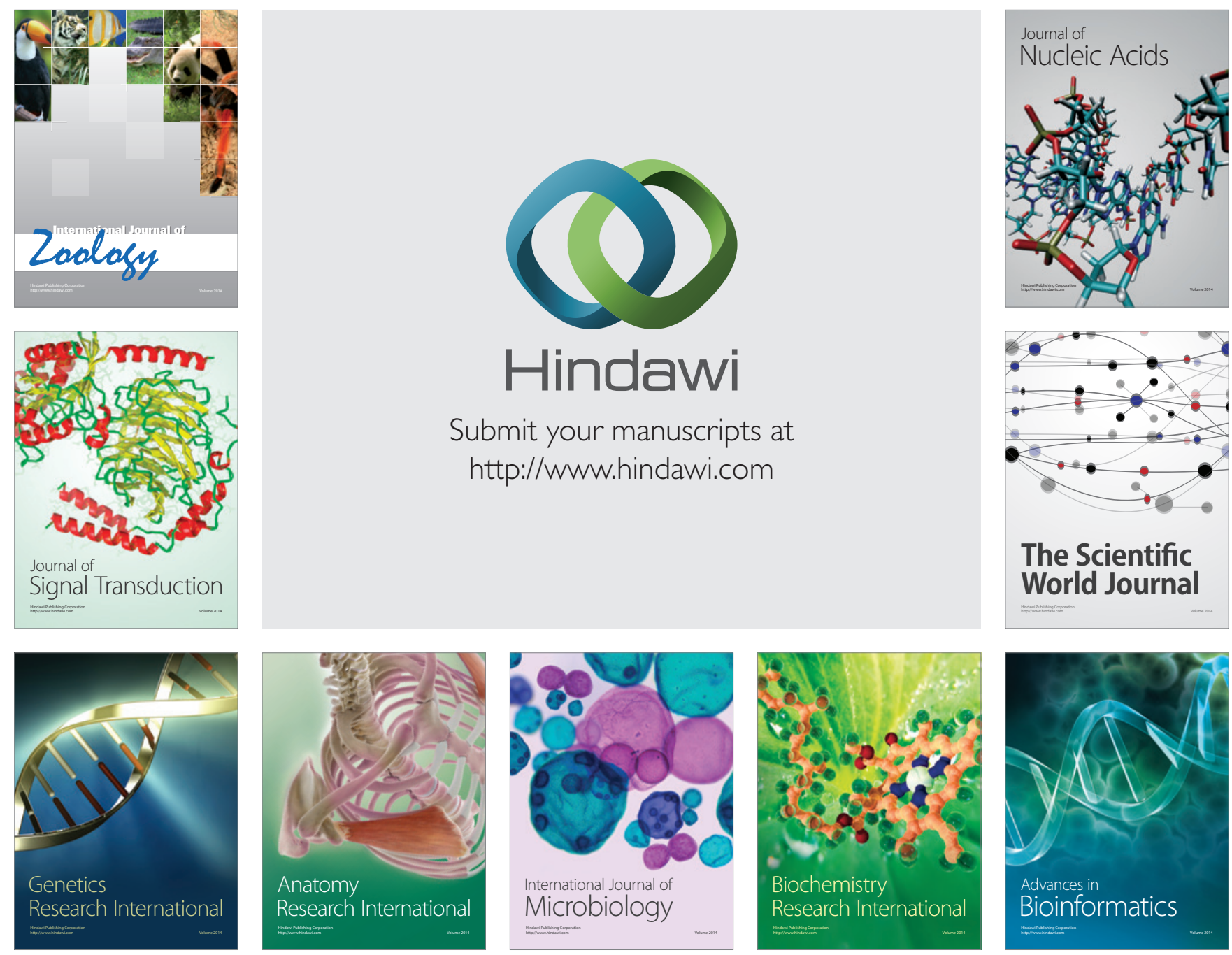

The Scientific World Journal
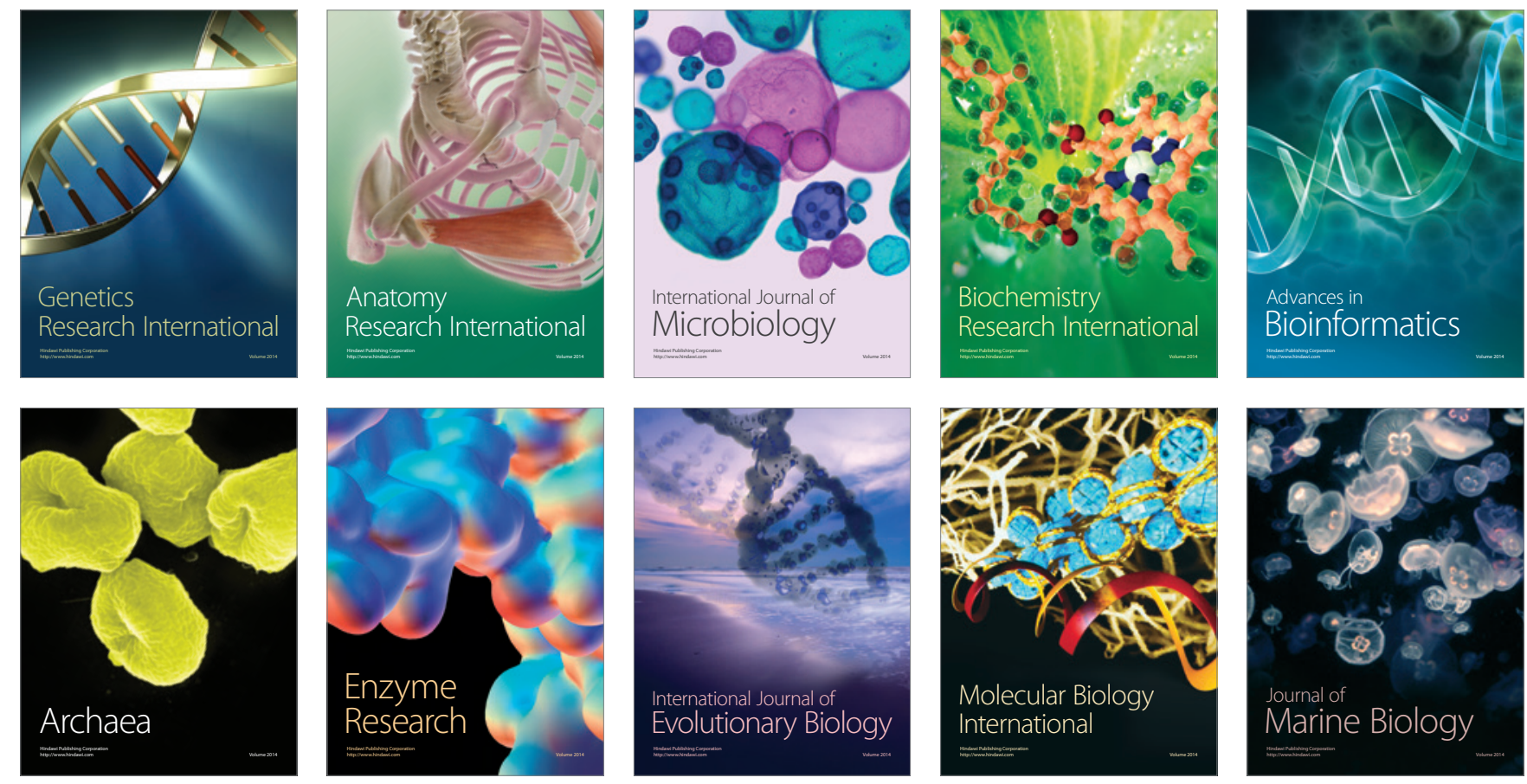